\title{
Geological fluid flow in sedimentary basins
}

\section{Les fluides géologiques dans les bassins sédimentaires}

\author{
Aurélien Gay ${ }^{1, *}$ and Sébastien Migeon ${ }^{2}$ \\ ${ }^{1}$ Géosciences Montpellier, UMR 5243-CC 60, Université Montpellier 2, place E.-Bataillon, 34095 Montpellier cedex 05, France \\ 2 GEOAZUR, UMR7329, 250 rue Albert-Einstein, Les Lucioles 1, Sophia-Antipolis 06560 Valbonne, France
}

\section{Introduction}

For over 50 years, sedimentary basins have been considered as the lithosphere's surface film, belonging to the subsurface domain and containing the vast majority of accessible mineral and energy resources. Beyond their human use, sedimentary basins are more importantly the ultimate exchange interface between the earth's main reservoirs. Firstly, between the upper lithosphere and the atmosphere-hydrosphere reservoirs, exchanges are mainly vertical. Next, between the onshore reservoirs, i.e., on the continental part, and the offshore reservoirs, i.e., in the submerged part of the margins, exchanges are lateral and may take place over great distances. Unexpected low accumulations and/or dry holes are becoming more frequent in petroleum exploration and gaining an understanding on lateral migration of fluids and bypass system are one of the geological challenges that must be addressed to reach ultimate reservoirs in the coming years.

In such context, the French coordination program Action Marges (AM) has been launched in 2008 in order to focus the continental margin research on a cross disciplinary research and develop new concepts that have an important impact for society, for resources and for risk assessment. The Action Marges project is coordinated by INSU with financial contribution of TOTAL, CNRS, BRGM and IFREMER. One of the themes is dedicated to "Fluids - Organic Matter Mineral Matter" (FO3M) and the challenge was to define fluid flow as the centerpiece of a cycle starting from the organic matter preservation at seabed, its transformation during burial forming fluids, the upward fluid migration through finegrained sediments, the temporarily fluid storage into reservoirs such as sedimentary bodies or gas hydrates, the fluid expulsion at seafloor, to its implications on seabed stability or climate change.

This special issue on geological fluid flow in sedimentary basins aims at bringing together recent results from the scientific community involved in the FO3M project since 2012, with a special focus on the interplay between mineralogical, geochemical, physical and biological processes

*Corresponding author: aurelien.gay@gm.univ-montp2.fr occurring during fluid remobilization and migration within the shallow interval $(0-1000 \mathrm{~m})$ of sedimentary basins.

\section{Organic matter preservation and shallow fluid migration}

The initial sediment lithification starts with complex interactions involving minerals, shallow interstitial water, decomposing organic matter and living organisms. This is the eogenesis domain $(0-1000 \mathrm{~m}$ below seafloor) in which the sediments are subjected to physical, chemical and mechanical transformations defining the early fabric of rocks (Fig. 1). This interval is intensively prospected for its geological resources (hydrocarbons, metal deposits, geothermal energy). In most basins worldwide, it consists of very fine-grained sediments and it is supposed to play the role of a seal for fluid migration. Local sand-prone deposits of various origin, architecture and thickness can also be found, acting as pathways or reservoirs for fluids.

For the first time, the solid phase BrOrg has been evidenced as a conservative tracer of the debromination of sedimentary organic matter in a shallow core $(<50 \mathrm{~m})$ taken on the Nile deepsea fan (Murat et al., this issue). The rate of debromination illustrates the complex interplay between organic matter, microbes and inorganic compounds in unconsolidated sediments. It obviously depends on the TOC, meaning that it increases with TOC up to $3 \%$ due to the availability of the bacterial population. However, the debromination process decreases for TOC higher than $4 \%$. This is of high interest for organic-matter transformation as the BrOrg tracer determines how fine-grained organic-rich intervals become potential source rocks at depth and how bacterial populations modify fluids and organic matter characteristics during early stages of burial (Fig. 1). In addition, the BrOrg can be used as a tool for defining intervals that were "fluid engineers" in the eogenesis domain once the organic matter has been transformed at depths where diagenesis is the most active process for lithification $(>1000 \mathrm{~m}$ below seafloor).

However, the eogenesis domain is commonly affected by polygonal faulting due to a volume loss by contraction of smectite-prone clay sediments during burial (Andresen and Huuse, 2011; Cartwright, 2011; Gay et al., 2007). This process 


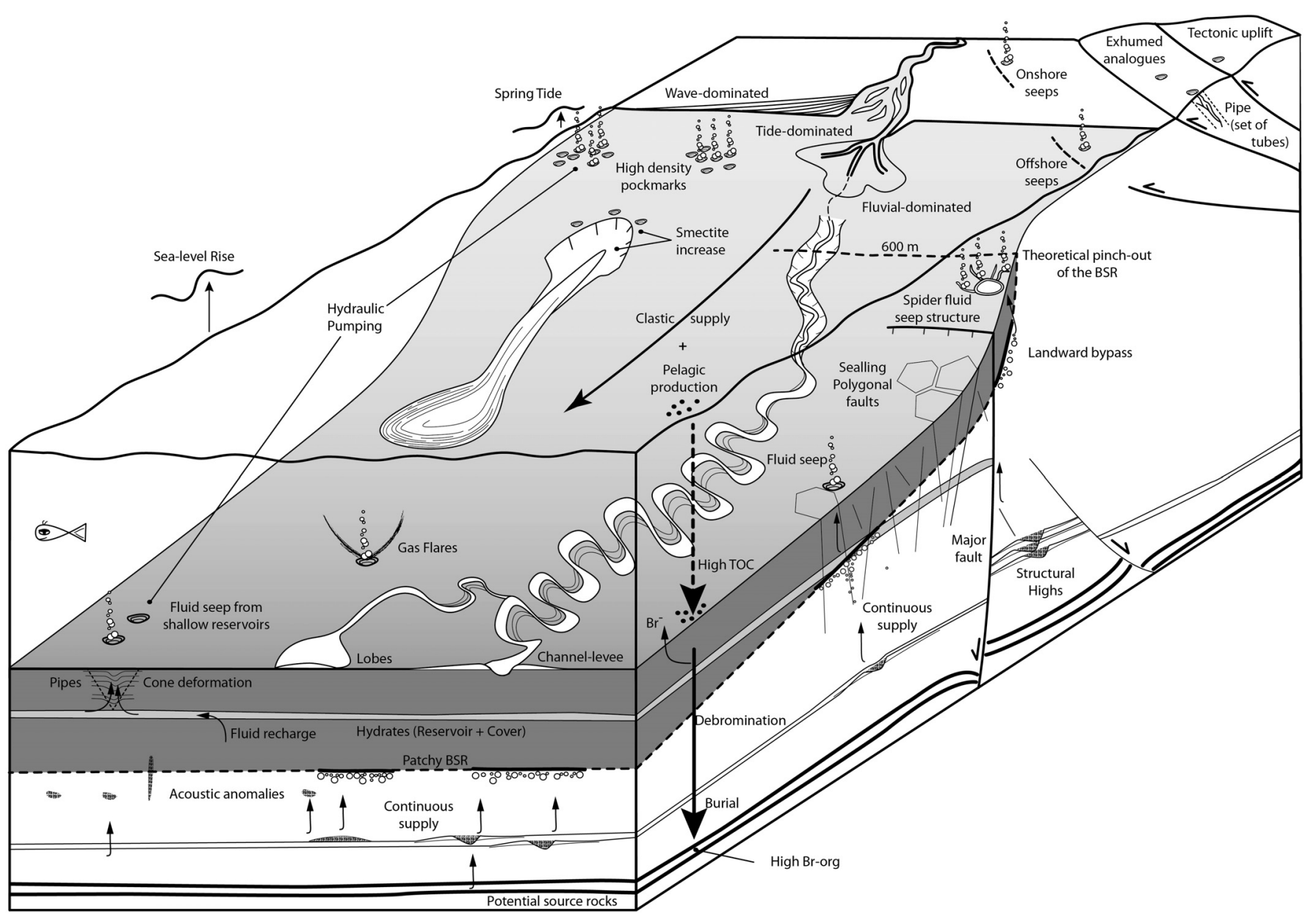

Fig. 1. Schematic block illustrating new developments since 2012 in geological fluid production, migration and expulsion in sedimentary basins, based on studies conducted through the FO3M thematic action in the Action Marges project.

is of high interest to constrain fluids circulation within fractured reservoirs and/or preservation of the sediment-cover integrity but it is still not well constrained as this interval can either promote the migration of fluids from underlying reservoirs (Gay et al., 2004; Lonergan et al., 1998). In addition, mineralized fluids intensify diagenesis in the fracture planes, rendering this interval all the more impermeable (Laurent et al., 2012). The detailed analysis of the geometric relationships between highimpedance seismic anomalies and polygonal fault pairs reveals that they can act as a seal during early stages of burial (Ho et al., 2016). In the Congo Basin, the Pliocene-present interval contains widespread fluid escape features, at seabed and in the subsurface, indicating past and ongoing bypass of the regional seal which is intensely affected by a major polygonal fault system (Gay et al., 2004). Casenave et al., this issue have shown that this polygonal fault interval might also have sealing properties. In this case, fluids are mainly driven along major faults to reach the seabed, leading to more focused and localized fluid seeps (Fig. 1). The next challenge will be then to define where, when and how does this polygonal fault interval occur. This can only be done by understanding the behavior of clay grains and fluids during early burial stages.

In the Sobrarbe Delta (Eocene Ainsa Basin), diagenetic conditions were limited to low temperatures (up to $75^{\circ} \mathrm{C}$ ), meaning that sediments have been buried to a maximum of $2 \mathrm{~km}$ (Odonne et al., this issue). Both some sliding surfaces and their surrounding deposits were investigated. Results reveal higher smectite ratio close to the sliding surfaces and smectites were found at the wall of dissolution voids of K-feldspars (Fig. 1). This indicates that fluids preferentially circulated following the sliding surfaces that acted as major heterogeneity within the sediment pile. In these conditions, clay minerals such as smectite appear as a robust marker of shallow fluid circulation as the kaolinite requires a temperature of 130 $140{ }^{\circ} \mathrm{C}$ to change into illite.

\section{Seafloor fluid seepage}

Once fluids (water, gas, oil or a mix) reach the seafloor, they are expelled in the water column forming sub-circular depressions called pockmarks (Hovland and Judd, 1988). Pockmarks have been reported in various depositional systems at water depths ranging from $30 \mathrm{~m}$ to over $3000 \mathrm{~m}$ (for a detailed review see Rollet et al., 2006; Gay et al., 2007). They generally form in unconsolidated, fine-grained deposits. They are cone-shaped circular or elliptical depressions, ranging from a few meters to $800 \mathrm{~m}$ or more in diameter 
and from $1 \mathrm{~m}$ to $80 \mathrm{~m}$ in depth. They concentrate in fields extending over several square kilometers. For the last decade, discoveries of new fluid seep structures were not reported although both academic and industrial surveys intensified.

However, the use of high-resolution geophysical imagery systems leads to the identification of unknown high-density field of pockmarks (about 3500 sub-circular pockmarks per square $\mathrm{km}$ ) in unsuspected shallow marine environment (about $35 \mathrm{~m}$ water depth) like the Bay of Concarneau (France) (Baltzer et al., this issue). The pockmarks appear to be active as the fields limits coincide with the settlements of Haploops tube mats covering muddy deposits. To date, this is the highest density of pockmarks ever found in marine environment (Fig. 1). The acquisition of bathymetry and other geophysical tools in the same area in 2011 and 2014 was essential in order to determine lasting of Haploops communities related to fluid seeps within pockmarks.

In the Lower Congo Basin (LCB), the combined use of various datasets acquired during the last 15 years and including multibeam bathymetry, seismic data, seafloor videos, seafloor samples and chemical analyses of both carbonate samples and of the water column allowed the identification of two distinctive associations of pockmark-like seabed venting structures, located in water depths of 600-700 m (Casenave et al., this issue). These two features are called "spiders structures" because of their morphology consisting of a large and flat sub-circular depression (the body) surrounded by elongated depressions (the legs). The body consists of muddy low-reflective hemipelagic sediments, covered by patches of bacterial mats and empty shells, and seems dormant while the legs appear to be the present-day active seep location (Fig. 1). This observation is similar to what was already described for more conventional pockmark structures on the Nile margin (Bayon et al., 2008; Dupré et al., 2010; Migeon et al., 2014; Praeg et al., 2014) but it is the first time that such a specific seabed planform morphology associated with such a fluidcirculation activity is reported.

Pockmarks and gas seeps can also be detected on acoustic records as long as they are active (Dupré et al., 2015). This is the case in the Bay of Concarneau where acoustic flares were identified on Chirp profiles (Baltzer et al., this issue). This is also the case on the Romanian sector of the Black Sea where widespread gas flares were evidenced in the water column related to high fluid fluxes escaping from the seabed (Riboulot et al., this issue). Gas flares are a useful tool to easily identify active pockmarks during multibeam and 2D high-resolution seismic surveys (Fig. 1). They develop above active pockmarks and might be related to the presence of a gas-hydrate stability zone.

\section{From the source to the seafloor}

On the geophysical record, either 2D or 3D seismic data, vertical fluid pathways called pipes (or chimneys) are usually imaged as systematic disruptions and/or offset of the reflections within sub-vertical zones, 50-1000 $\mathrm{m}$ wide and up to $1000 \mathrm{~m}$ high (Løseth et al., 2011). This interpretation is also supported by observation of amplitude enhancement or dimming. On seismic profiles, the internal structure of pipes is characterized by bent reflections with offset upward (pull-up effect) or downward (pull-down effect) relative to the host stratigraphy by 20 to $150 \mathrm{~ms}$ TWT. Pipes are interpreted to represent a high-permeable vertical zone called a seal bypass system (Cartwright et al., 2007). They are thought to be caused by high fluid overpressure hydro-fracturing sediments of low permeability (Arntsen et al., 2007; Rodrigues et al., 2009). This geophysical characterization seems actually well constrained in space and time. However, using a set of derived seismic attributes, it is now possible to identify the root of a pipe (i.e., the depth at which fluids are originating from) and the paleo-pockmark surface (i.e., the level representing the paleo-seafloor at the time the fluid expulsion started [was active?]). In the Gulf of Lion, the fluid pipe induces a deformation of surrounding unconsolidated sediments during upward migration, leading to the formation of a cone in cone or V-shaped structures (Gay et al., this issue). A multiattribute calculation made on $3 \mathrm{D}$ seismic data allows the precise 3D mapping of the points of fluid injection while the top of the cone structure marks the top of the focused migration (Fig. 1).

It is classically invoked that most of the fluids reaching the seabed are originating from shallow buried levels (Fig. 1) although when carbonate crusts build at the seafloor there is undoubtedly a contribution of deeper fluids allowing oil or thermogenic gas to be expelled (León et al., 2010, 2014). This is the case in the Gulf of Lion (Gay et al., this issue), on the Romanian shelf (Riboulot et al., this issue) or in the Bay of Concarneau (Baltzer et al., this issue) where fluid releasing is attested. These vertical chimneys or pipes are among other acoustic anomalies usually present in the shallow sub-surface due to gas accumulations or carbonate precipitation (Fig. 1). In the Lower Congo Basin, such anomalies were identified on either 3D seismic data, HR 3D seismic data or 2D-AUV data (Casenave et al., this issue) corresponding to bright spots, elongated acoustic anomalies or black patches.

However, even with 3D seismic imagery, the full architectural pattern of the fluid network remains very complex to determine. Only a few examples of modern fluid-related systems have been studied in details at sea, probably because of the limited number of areas where VHR investigations of the seafloor/sub-surface together with $3 \mathrm{D}$ seismic data exists. It is then possible to better understand these features on field analogues, once the stratigraphic intervals hosting them have been uplifted due to tectonic activity and brought above the sea-level (Fig. 1). For instance, in the uplifted accretionary prism of Hikurangi Margin (NewZealand), tubular concretions are outcropping in several Miocene mudrocks intervals (Malié et al., this issue). Most of the pipes are sub-vertical with their length-axis perpendicular or sub-perpendicular to the bedding plane. They are 10 to $40 \mathrm{~cm}$ in diameter and $50 \mathrm{~cm}$ to $10 \mathrm{~m}$ in length. In some cases, they are inter-connected, forming a real plumbing system. A direct comparison with seismic-scale features is still not realistic to manage because their dimensions are far below the seismic resolution. Anyway, this suggests that a fluid pipe few hundred-meters wide identified on the seismic record is most probably a set of several small-scale pipes together propagating in a large area of sediment impregnated with fluids (Fig. 1). This should be the target for the development of future research fields. 


\section{The dual role of hydrates in cover integrity}

The sub-vertical fluid pipes (or chimneys) are often disrupted at depth by a high-amplitude reflection parallel to the seafloor. This reflection is interpreted as a bottom-simulating reflector (BSR) corresponding to the lower thermodynamic limit of the gas-hydrate stability zone (Shipley et al., 1979; Kvenvolden 1988; Hyndman and Spence, 1992). This can be also considered as the top of the free-gas zone beneath the hydrates (MacKay et al., 1994). BSRs are characterized by a reverse polarity reflection compared to the seafloor. This is due to a decrease in seismic impedance and, therefore, of seismic velocity. The main restriction for the occurrence of hydrates is the presence/supply of sufficient amounts of stabilizing gas molecules (Rempel and Buffett, 1997). As outlined by Egorov et al. (1999), the steady-state model for gas hydrates requires a methane flux from below to compensate for its diffusive dissipation into the pore water (Sultan et al., 2014). This statement is confirmed on the Romanian shelf where BSRs are deflected upward (Riboulot et al., this issue), suggesting a localized positive heat flow anomaly probably due to an ascending movement of fluids through the sedimentary column (De Batist et al., 2002; Gay et al., 2006). It means that gas hydrates are locally not impermeable, allowing fluids to migrate upward along any major discontinuity such as faults, and then to form pockmarks at the seabed (Fig. 1). So, there is a close association between BSRs at depth, indicating an active fluid flux, and seafloor pockmarks. This is also the case in the Lower Congo Basin where the new "spider structures" are located above patches of BSR (Casenave et al., this issue).

As gas hydrates are usually considered impermeable, additional free gas may migrate laterally right beneath the hydrates. Once they find a way up, they can escape to the seabed. On the seismic record, this kind of seepage is often evidenced by hyperbolae located at the landward termination of the BSR and overlaid with seafloor gas escape structures (Fig. 1) (Riboulot et al., this issue; Casenave et al., this issue).

Gas hydrates have a dual role in sedimentary basins as they temporarily store fluids migrating from deeper geological horizons to their stability zone or as free gas beneath them and they avoid fluids to reach the seabed with properties similar to a barrier. In consequence, they can be considered as both a reservoir and a cover in the shallow subsurface (Fig. 1).

\section{Triggering and control mechanisms}

In the uplifted accretionary prism of Hikurangi Margin (New-Zealand), trending of fossil tubular carbonate concretions coincides with tectonic lineament suggesting that the main factor controlling the fluid expulsion and location is the tectonic activity (Malié et al., this issue). It is suggested that the tectonic uplift together with fault activity can shift the depth of the Hydrate Stability Zone (HSZ), leading to dissociation of pre-existing hydrates and releasing of methane.

Gas hydrates are also "climate sensitive" as they form or dissolve in response to sea-level variations controlling bottom seawater temperatures. In the Lower Congo Basin, the various stratigraphic levels hosting fluid escape structures have been correlated to sea-level rises following the latest Holocene lowstands (Casenave et al., this issue). This is due to free gas naturally migrating landward due to the pronounced tilting of the base of the gas hydrate stability zone at $600-700 \mathrm{~m}$ water depths (close to theoretical pinch-out of the BSR).

This relation with sea-level variations has also been evidenced in the Gulf of Lion where most of the modern pockmarks were formed during the last sea-level rise (Gay et al., this issue). León et al. (2014) have shown that in the western Mediterranean Sea, the propagation of internal waves alongshore may act together with the general sea-level rise at the beginning of the transgressive period as a hydraulic pump for fluids trapped at shallow depths, resulting in the formation of pockmarks (Fig. 1). It suggests that, at the beginning of each transgression, large amount of methane-rich fluids might be released into the ocean and atmosphere, possibly increasing the greenhouse effect (Dunkley Jones et al., 2010).

The effect of hydraulic pumping can be responsible for the formation of the large fields of pockmarks in the Bay of Concarneau (Baltzer et al., this issue). At a shorter time-scale, the high-frequency expulsion activity may be related to the action of spring tides (Fig. 1). Although the initial pockmark craters are thought to be formed during seismic events (Baltzer et al., 2014), pockmarks could be activated when the tidal pressure would be high enough during spring tides, leading to the formation of plumes in the water column.

As previously proposed by Hasiotis et al. (1996), these observations imply that gas supply towards pockmarks is a continuous process during the life-span of the seep structure (Fig. 1). It also means that the sediments within the migration pathways are loaded with gas, which is of high interest for seafloor hazards.

\section{Conclusion}

Recent studies of fluid migrations in sedimentary basins have shown that these phenomena are ubiquitous and interact with the surrounding sedimentary rocks over the basin's history, from its early opening stages, to the mature infilling, or even the ultimate exhumation stages. Finally, these fluids act as major markers for the geodynamic events that structure the basins.

In order to understand the role of fluids in sedimentary basins, several challenges must be met. We must, in particular, determine the source of the fluids, their pathways and the timing of these migrations and releasing at the seafloor. Thus, depending on the geodynamic context of a given basin and on its evolution over time, several fluid migration histories may overlap, though these fluid events are all preserved in the sedimentary record. The goal is thus to identify a number of geophysical, mineralogical and geochemical markers of fluid migration and expulsion. They are closely controlled:

- by early sediment deformations and fracturing;

- by the location of bodies and sedimentary sequences likely to temporarily store and/or conduct fluids laterally all along the margin;

- by allocyclic phenomena such as sea-level variations.

In this special issue, the methods have combined complementary approaches to analyse fluid migrations in sedimentary basins: 
- geophysical characterisation based on 2D, 3D and 2DAUV seismic data, core and exploratory well data;

- sedimentological and mineralogical characterisation based on petrophysical data and crystallographic and texture analyses;

- identification of geochemical markers on samples collected at various depths of the sedimentary column up to the surface;

- definition of the mechanical parameters triggering and controlling fluid re-mobilisation.

The final goal of this research field will be to generate a concept of "fluid sequences" that, in a similar fashion to sequence stratigraphy, will be used as a direct approach to determine the migration pathways and potential traps, and to quantify the volume and nature of expelled fluids. This is of major importance as it will help determining the timing and activity of seafloor fluid expulsion leading to geohazard assessment (catastrophic fluid blow-out, landslide triggering, etc.). As a reverse approach, it will make possible to define the evolutionary status of a sedimentary basis and to infer its geodynamic context at any given period of its history. The aim is thus to significantly improve fluid expulsion models in sedimentary basins, which is a challenge for basin exploration (open window over the petroleum system, seafloor stability and fluid accumulation).

Acknowledgements. We would like to thank Cécile Robin, Gianreto Manatschal and Sylvie Leroy who have managed the scientific board of Action Marges project for the last 8 years. We thank all partners involved in this project, such as TOTAL, IFREMER, BRGM and CNRS-INSU.

\section{References}

Andresen KJ, Huuse M. 2011. "Bulls-eye" pockmarks and polygonal faulting in the Lower Congo Basin: relative timing and implications for fluid expulsion during shallow burial. Marine Geology 279 (1-4): 111-127.

Arntsen B, Wensaas L, Løseth H, Hermanrud C. 2007. Seismic modelling of gas chimneys. Geophysics 72: 251-259.

Baltzer A, Ehrhold A, Rigolet C, Souron A, Cordier C, Clouet H, et al. 2014. Geophysical exploration of an active pockmark field in the Bay of Concarneau, southern Brittany, and implications for resident suspension feeders. Geo-Marine Letters 34: 215-230.

Baltzer A, Reynaud M, Ehrhold A, Fournier J, Cordier C, Clouet C. 2017. Space-time evolution of a large field of pockmarks in the Bay of Concarneau (NW Brittany). Bull. Soc. géol. Fr. 188: 23.

Bayon G, Loncke L, Dupré S, Caprais J-C., Ducassou E, Duperron S, et al. 2008. Multi-disciplinary investigation of fluid seepage on an unstable margin: The case of the Central Nile deep sea fan. Marine Geology 261 (1-4): 92-104.

Cartwright J. 2011. Diagenetically induced shear failure of finegrained sediments and the development of polygonal fault systems. Marine and Petroleum Geology 28: 1593-1610.

Cartwright J, Huuse M, Aplin AC. 2007. Seal bypass system. AAPG bulletin 91 (8): 1141-1166.

Casenave V, Gay A, Imbert P. 2017. Spider structures: records of fluid venting from methane hydrates on the Congo continental slope. Bull. Soc. géol. Fr. 188: 27.
De Batist M, Klerkx J, Van Rensbergen P, Vanneste M, Poort J, Golmshtok A, et al. 2002. Active Hydrate Destabilization in Lake Baikal, Siberia? Terra Nova 14 (6): 436-442.

Dunkley Jones T, Ridgwell A, Lunt DJ, Maslin MA, Schmidt DN, Valdes PJ. 2010. A Palaeogene perspective on climate sensitivity and methane hydrate 684 instability. Philosophical Transactions of the Royal Society a-Mathematical Physical and Engineering Sciences 368 (1919): 2395-2415.

Dupré S, Woodside J, Klaucke I, Mascle J, Foucher J-P. 2010. Widespread active seepage activity on the Nile Deep Sea Fan (offshore Egypt) revealed by high-definition geophysical imagery. Marine Geology 275 (1-4): 1-19.

Dupré S, Scalabrin C, Grall C, Augustin JM, Henry P, Sengör AM, et al. 2015. Tectonic and sedimentary controls on widespread gas emissions in the Sea of Marmara: Results from systematic, shipborne multibeam echo sounder water column imaging. Journal of Geophysical Research: Solid Earth 120: 2891-2912.

Egorov AV, Crane K, Vogt PR, Rozhkov AN. 1999. Gas hydrates that outcrop on the sea floor: stability models. Geo-Marine Letters 19: 89-96.

Gay A, Lopez M, Cochonat P, Sermondadaz G. 2004. Polygonal faultfurrows system related to early stages of compaction - upper Miocene to recent sediments of the Lower Congo Basin. Basin Research 16: 101-116.

Gay A, Lopez M, Cochonat P, Séranne M, Levaché D, Sermondadaz G. 2006. Isolated seafloor pockmarks linked to BSRs, fluid chimneys, polygonal faults and stacked Oligocene-Miocene turbiditic palaeochannels in the Lower Congo Basin. Marine Geology 226: 25-40.

Gay A, Lopez M, Berndt C, Séranne M. 2007. Geological controls on focused fluid flow associated with seafloor seeps in the Lower Congo Basin. Marine Geology 244: 68-92.

Gay A, Cavailhes T, Grauls D, Marsset B, Marsset T. 2017. Repeated fluid expulsions during events of rapid sea-level rise in the Gulf of Lion, western Mediterranean Sea. Bull. Soc. géol. Fr. 188: 24.

Hasiotis T, Papatheodorou G, Kastanos N, Ferentinos G. 1996. A pockmark field in the Patras Gulf (Greece) and its activation during the 14/7/93 seismic event. Marine Geology 130: 333-344.

Ho S, Caruthers D, Imbert P. 2016. Insights into the permeability of polygonal faults from their intersection geometries with Linear Chimneys: a case study from the Lower Congo Basin. Carnets Géologie 16(02): 17.

Hovland M, Judd J. 1988. Seabed pockmarks and seepages. Impact on Geology, Biology and Marine Environment. London: Graham and Trotman, $293 \mathrm{p}$.

Hyndman RD, Spence GD. 1992. A seismic study of methane hydrate marine bottom simulating reflectors. JGR 97: 6683-6698.

Kvenvolden KA. 1988. Methane hydrate - a major reservoir of carbon in the shallow geosphere? Chemical Geology 71: 41-51.

Laurent D, Gay A, Baudon C, Berndt C, Soliva R, Planke S, et al. 2012. High-resolution architecture of a polygonal fault interval inferred from Geomodel applied to 3D seismic data from the Gjallar Ridge, Vøring Basin, Offshore Norway. Marine Geology 332-334: 134-151.

León R, Somoza L, Medialdea T, Hernández-Molina FJ, Vázquez JT, Díaz-del-Rio V, et al. 2010. Pockmarks, collapses and blind valleys in the Gulf of Cádiz. Geo-Marine Letters 30 (3-4): 231-247.

León R, Somoza L, Medialdea T, Gonzalez FJ, Gimenez-Moreno CJ, Perez-Lopez R. 2014. Pockmarks on either side of the Strait of Gibraltar: formation from overpressured shallow contourite gas reservoirs and internal wave action during the last glacial sea-level lowstand? Geo-Marine Letters 34 (2-3): 131-151. 
Lonergan L, Cartwright J, Jolly R. 1998. The geometry of polygonal fault in Tertiary mudrocks of the North Sea. Journal of Structural Geology 20: 529-548.

Løseth H, Wensaas L, Arntsen B, Hanken NM, Bsire C, Graue K. 2011. $1000 \mathrm{~m}$ long gas blow-out pipes. Marine and Petroleum Geology 28 (5): 1047-1060.

MacKay ME, Jarrard RD, Westbrook GK, Shipboard Scientific Party of Ocean Drilling Program Leg 146. 1994. Origin of bottomsimulating reflectors: Geophysical evidence from the Cascadia accretionary prism. Geology 22: 459-462.

Malié P, Bailleul J, Chanier F, Toullec R, Mahieux G, Caron V, et al. 2017. Spatial distribution and tectonic framework of fossil tubular concretions as onshore analogues of cold seep plumbing systems, North Island of New Zealand. Bull. Soc. géol. Fr. 188: 25.

Migeon S, Ceramicola S, Praeg D, Ducassou E, Dano A, Ketzer JM, et al. 2014. Post-failure Processes on the Continental Slope of the Central Nile Deep-Sea Fan: Interactions Between Fluid Seepage, Sediment Deformation and Sediment-Wave Construction. In: Krastel S, et al., eds. Submarine Mass Movements and Their Consequences. Advances in Natural and Technological Hazards Research. Springer 37, pp. 117-127.

Murat A, Beaufort D, Hebert B, Baudin F, Bernasconi S, Ducassou E, et al. 2017. Post-depositional evolution over a time scale of 1 million years of eastern Mediterranean organic-rich and organicpoor sediments: new insights on the debromination and layersilicate markers. Bull. Soc. géol. Fr. 188: 21.

Odonne F, Beaufort D, Munck R, Bourrières L, Darrozes J. 2017. Smectite as a marker of telogenetic process along structural heterogeneities of sedimentary basin: Case study of the Eocene submarine slide surfaces of the Ainsa Basin. Bull. Soc. géol. Fr. 188: 22.
Praeg D, Ketzer JM, Augustin AH, Migeon S, Ceramicola S, Dano A, et al. 2014. Chapter 13. Fluid Seepage in Relation to Seabed Deformation on the Central Nile Deep-Sea Fan, Part 2: Evidence from Multibeam and Sidescan Imagery. In Submarine Mass Movements and Their Consequences - 6th International Symposium - Advances in Natural and Technological Hazards Research, vol. 37, pp. 141-150.

Rempel AW, Buffett BA. 1997. Formation and accumulation of gas hydrate in porous media. Journal of Geophysical Research 102 (B5): 10151-10164.

Riboulot V, Cattaneo A, Scalabrin C, Gaillot A, Jouet G, Ballas G, et al. 2017. Control of the geomorphology and gas hydrate extent on widespread gas emissions offshore Romania. Bull. Soc. géol. Fr. 188: 26.

Rodrigues N, Cobbold PR, Løseth H. 2009. Physical modelling of sand injectites. Tectonophysics 474: 610-632.

Rollet N, Logan GA, Kennard JM, O'Brien PE, Jones AT, Sexton M. 2006. Characterisation and correlation of active hydrocarbon seepage using geophysical data sets: an example from the tropical, carbonate Yampi Shelf, Northwest Australia. Marine and Petroleum Geology 23: 145-164.

Shipley TH, Houston MH, Buffler RT, Shaub FJ, McMillen KJ, Ladd JW, et al. 1979. Seismic evidence for widespread possible occurrence of gas-hydrate horizons or continental slopes and rises. AAPG Bulletin 63: 2204-2213.

Sultan N, Bohrmann G, Ruffine L, Pape T, Riboulot V, Colliat JL, et al. 2014. Pockmark formation and evolution in deep water Nigeria: Rapid hydrate growth versus slow hydrate dissolution. Journal of Geophysical Research, Solid Earth 119: 2679-2694.

Cite this article as: Gay A, Migeon S. 2017. Geological fluid flow in sedimentary basins, Bull. Soc. géol. Fr. 188 : E3. 